\title{
Synthesis of a Multifunctional Oxazolo[5,4-e][1,4]diazepine Skeleton
}

\author{
Gundurao Kolavi, ${ }^{\dagger,}$, a Isak Im, ${ }^{\dagger, \#, a}$ Yong-Chul Kim, ${ }^{\dagger, \star, *}$ and Hyojin Ko ${ }^{\ddagger, *}$ \\ ${ }^{\dagger}$ Department of Life Science, Graduate-program of Medical System Engineering, \\ Gwangju Institute of Science and Technology, Gwangju 500-712, Korea. ${ }^{*}$ E-mail: kohyojin@gist.ac.kr \\ ${ }^{\S}$ Current address: Department of Chemistry, University of Alabama at Birmingham, AL 35294

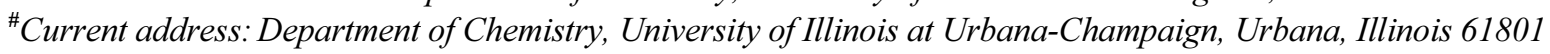 \\ Received October 4, 2010, Accepted December 25, 2010
}

Key Words : Oxazolodiazepine, Privileged scaffold

1,4-Benzodiazepines have been the object of intense investigation due to their potential for use in various therapeutic utilities, such as anxiolytic and anticonvulsant activities $^{1}$ as well as various biological functions as a privileged skeleton. This skeleton has been applied in the development of cholecystokinin (CCK) receptor A and B antagonists, ${ }^{2}$ opioid receptor ligands, ${ }^{3}$ platelet-activating factor antagonists, ${ }^{4}$ human immuno-deficiency virus transactivator Tat antagonists, ${ }^{5}$ reverse transcriptase inhibitors, ${ }^{6}$ and ras farnesyltransferase inhibitors. ${ }^{7}$ During the past decade attention has also been diverted to the synthesis of 1,4-diazepinones with a fused heterocyclic system in place of the benzene ring ${ }^{8,9}$ to explore the heterocycle for various biological applications. In particular, triazolo- ${ }^{10}$ thieno- ${ }^{11}$ pyrrollo- ${ }^{12}$ indole- ${ }^{13}$ and pyrido-diazepines ${ }^{14}$ have exhibited new pharmacological activities. Here, we report on the synthesis of a new heterocycle-fused diazepine derivative, oxazolo[5,4-e][1,4]diazepine-5,8-dione (Figure 1). As part of one of our drug discovery programs, we have developed synthetic strategies suitable for the introduction of multiple substituents on the oxazolodiazepine scaffold. The derivative of these strategies could be a useful intermediate in the synthesis of biologically active compounds.

Initial efforts regarding the synthesis of oxazolodiazepine skeleton using the conventional approach is shown in Scheme 1. Coupling reaction of Fmoc-glycine with ethyl 2amino-2-cyano-acetate generated compound $\mathbf{1}$ and followed by the treatment of hydrogen chloride gas in anhydrous acetone produced oxazole ring 2 . Various coupling agents such as EDC, PyBOP, and HATU were tried to condense the

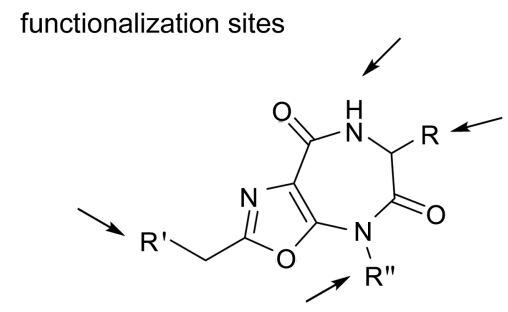

Figure 1. Structure of oxazolo[5,4-e][1,4]diazepine skeleton and sites for functionalization.

${ }^{\mathrm{a}}$ These authors contributed equally to the work primary amine of oxazole ring $\mathbf{2}$ with several Fmoc-amino acids to produce compound $\mathbf{3}$. Amino acid was converted to even acid chloride for carbonyl carbon being more prone to nucleophilic attack. However, due to low nucleophilicity of 5-aminooxazole amine, amide bond formation was not successful. It was determined that even simple acylation with acetyl chloride result in only an $8 \%$ yield.

It has been reported that the primary amine on the oxazole ring has low reactivity. Coupling 5-aminooxazole with various acid chloride resulted to form amide bond in poor yields. ${ }^{15}$ Generally free 5 -aminooxazoles are prone to ringopening in solution. ${ }^{16}$ Stable 5-aminooxazole are essentially limited to those bearing an electron-withdrawing group at the 4-poistion. ${ }^{17}$ In the case of compound 4, Ethyl ester group at 4-poision withdraws the resonant electrons including lone pair electrons of 5-aminooxaole. Amino group is also involved in the formation of intramolecular hydrogen bonding to the oxygen atom of the carbonyl group, ${ }^{18}$ which may cause redistribution of the electron density in the oxazole ring.

Thus, a new synthetic route of oxazolodiazepine skeleton was designed, as depicted in Scheme 2, having rhodium catalyzed amide incorporation as the key reaction step for

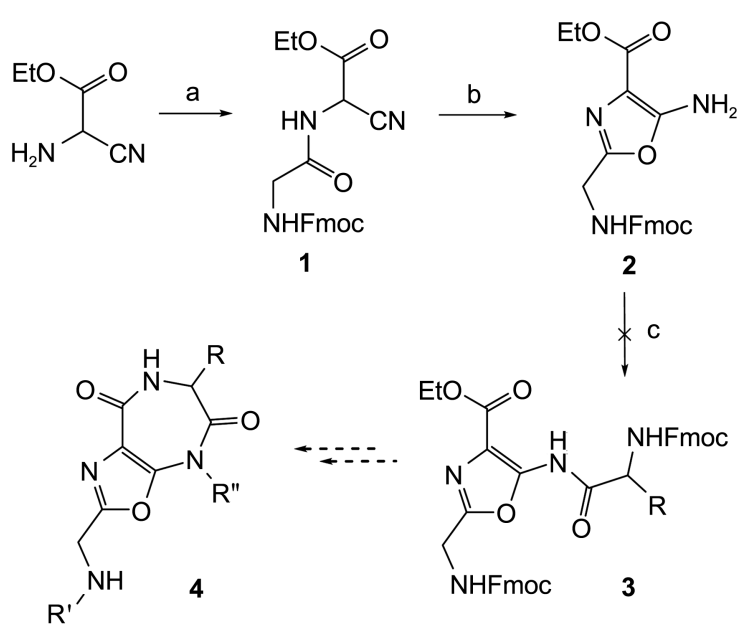

Scheme 1. Reagents and conditions: (a) Fmoc-GlyOH, EDC, $\mathrm{HOBt}$, NMP, 2 h, 64\%; (b) $\mathrm{HCl}$ (gas), anhydrous acetone, $3 \mathrm{~h}$, 95\%; (c) Fmoc-amino acids (acyl chloride) with various coupling reagents (EDC, PyBOP, HATU). 
<smiles>CC(=O)N[C@@H](CC(N)=O)C(=O)O</smiles>

5<smiles>CCCN(C[C@H](NC(C)=O)C(=O)OC)C(=O)[C@H](NC(=O)c1ccc(OC)cc1)C(=O)OC</smiles>

11<smiles>COC(=O)c1nc(-c2ccc(OC)cc2)oc1N(CCC#N)C[C@H](NC(C)=O)C(=O)OC</smiles>

12<smiles>NC[C@H](NC(=O)OCc1ccccc1)C(=O)O</smiles>

6<smiles>CC(C)C</smiles><smiles>COC(=O)c1nc(-c2ccc(OC)cc2)oc1N(CCC#N)C[C@H](N)C(=O)OC</smiles><smiles>C1CCCC1</smiles><smiles>COC(=O)[C@H](CN)NC(C)=O</smiles>

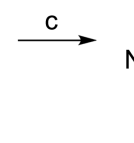<smiles>COC(=O)[C@H](CNCCC#N)NC(C)=O</smiles><smiles>COC(=O)CC(=O)N(CCC#N)C[C@H](NC(C)=O)C(=O)OC</smiles><smiles>COC(=O)[C@@H]1CN(CCCN)c2oc(-c3ccc(OC)cc3)nc2C(=O)N1</smiles>

Scheme 2. Reagents and conditions: (a) iodobenzenediacetate, EtOAc $+\mathrm{MeCN}+\mathrm{H}_{2} \mathrm{O}(2: 2: 1), \mathrm{rt}, 16 \mathrm{~h}, 94 \%$; (b) $\mathrm{SOCl}_{2}, \mathrm{MeOH}^{\circ}{ }^{\circ} \mathrm{C}, 2 \mathrm{~h}$ then rt, $8 \mathrm{~h}, 77 \%$; (c) acrylonitrile, $\mathrm{MeOH}$, reflux, $6 \mathrm{~h}, 86 \%$; (d) methylmalonylchloride, $N$-methylmorpholine, $\mathrm{CH}_{2} \mathrm{Cl}_{2},-15^{\circ} \mathrm{C}, 2 \mathrm{~h}$ then rt, $12 \mathrm{~h}$, $69 \%$; (e) 4-acetamidobenzenesulfonyl azide, Et 3 N, benzene, rt, 45 h, 60\%; (f) 4-methoxybenzamide, $\mathrm{Rh}_{2}(\mathrm{Oct})_{4}$, toluene, $80{ }^{\circ} \mathrm{C}, 4 \mathrm{~h}, 26 \%$; (g) $\mathrm{POCl}_{3}, \mathrm{DMF}, 60^{\circ} \mathrm{C}, 3 \mathrm{~h}, 40 \%$; (h) $\mathrm{Pd} / \mathrm{C}, \mathrm{H}_{2}, \mathrm{MeOH}, \mathrm{rt}, 3 \mathrm{~h}, 89 \%$; (i) $\mathrm{AlMe}_{3}$, toluene, rt, 2 h, $8 \%$.

the introduction of various groups at the oxazole ring system built by the cyclization of diamide compound 11.

The synthesis was initiated with the preparation of an unusual amino acid $\mathbf{6}$, by the Hoffmann rearrangement of Cbz protected asparagine (5, DL- $\mathrm{N}-\mathrm{CbzAsnOH})$ using iodobenzene diacetate, which in turn was esterified to afford the amino acid ester 7. The Michael addition of acrylonitrile with 7 yielded compound $\mathbf{8}$, and the subsequent coupling reaction of the secondary amine of $\mathbf{8}$ with methylmalonylchloride resulted in good yields in compound $\mathbf{9}$. Here, the nitrogen required for oxazole construction was attained by the following two step reaction. After the reaction of compound 9 with 4-acetamidobenzene sulfonyl azide to obtain the diazoderivative 10, the subsequent rhodium(II)octanoate catalyzed reaction of $\mathbf{1 0}$ with 4-methoxybenzamide in toluene resulted in compound 11. ${ }^{19}$ The incorporated amide and the carboxyester group of compound $\mathbf{1 1}$ was then cyclodehydrated using $\mathrm{POCl}_{3}$ with oxazole derivative 12 in a moderate yield. After the deprotection of the $\mathrm{Cbz}$ group of compound $\mathbf{1 2}$ under hydrogenolysis condition yielded compound $\mathbf{1 3}$, the final cyclization between the carboxymethyl ester on the oxazole ring and primary amine of compound $\mathbf{1 3}$ with trimethyl aluminum delivered the target compound 14. Note that the low yield of the cyclization reaction may be due to another carboxymethyl ester of 13, which could participate in the amide formation in an intermolecular manner, perhaps resulting in a polymerized product.

The conjugation of $\mathbf{1 3}$ (Figure 2) might make the ester less reactive, which might facilitate the other competing reactions include inter and intra molecular amidation (The $-\mathrm{NH}_{2}$ group has 3-different ester groups to react). Also 13 is<smiles>CCN(CC)c1oc(C(C)(C)C)nc1C(=O)OC</smiles>

Figure 2. Possible conjugation of oxazole ring 13.

satirically crowded leading to improper orientation of the groups, which might keep the groups (ester and amine) away from each other hence the less yield of required amide $\mathbf{1 4}$. As the mixture is racemate, it may be only one of the enantiomers was involved in the reaction. Another reason of low yield we discussed was the reagent $\mathrm{AlMe}_{3}$. There is a report which $i-\mathrm{Bu}_{3} \mathrm{Al}$ reduced the nitrile to amine. ${ }^{20}$ It may be a similar type of reaction occurred with $-\mathrm{CN}$ group of $\mathbf{1 3}$.

To avoid these possibilities which result low yield of forming oxazolodiazepine, we decided to use simpler precursor for cyclization. Compound $\mathbf{1 8}^{21}$ and 19 were designed and synthesized through the several steps as shown in scheme 3. However, all trials failed to obtain $\mathbf{2 0}$ by using the coupling reagents and $\mathrm{AlMe}_{3}$. From these results, we assumed the weak reactivity of oxazole ring is a main problem to create the amide bond.

In summary, we achieved the multistep synthesis of a novel heterocyclodiazepine system, an oxazolodiazepine skeleton having potential for use in the construction of derivatives with diverse functional groups around the scaffold.

\section{Experimental Section}

General Procedure. Starting materials, reagents, and 


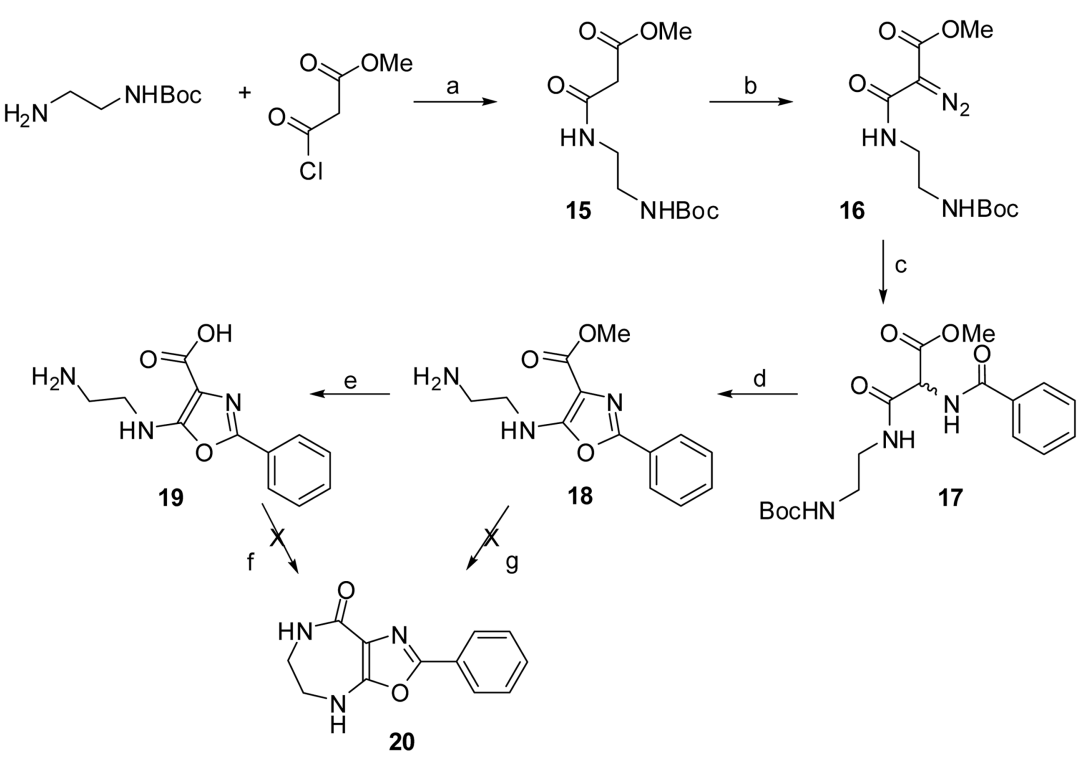

Scheme 3. Synthesis of simple oxazole ring for cyclization. Reagents and conditions: (a) $\mathrm{Et}_{3} \mathrm{~N}, \mathrm{CH}_{2} \mathrm{Cl}_{2}, 84 \%$; (b) 4-acetamidobenzensulfonyl azide, $\mathrm{Et}_{3} \mathrm{~N}$, toluene, $71 \%$; (c) benzamide, $\mathrm{Rh}_{2}(\mathrm{Oct})_{4}$, toluene, $80{ }^{\circ} \mathrm{C}, 61 \%$; (d) (i) TFAA, $\mathrm{ACN}, \mathrm{MW}, 130{ }^{\circ} \mathrm{C}, 5 \mathrm{~min},(\mathrm{ii})$ TMSOTf, $\mathrm{CH}_{2} \mathrm{Cl}_{2}, 75 \%$; (e) $5 \% \mathrm{NaOH}$ (aq), $80 \% \mathrm{MeOH}, 30 \mathrm{~min}, 88 \%$; (f) EDC, HOBt, DIPEA, DMF or PyBOP, DIPEA, DMF; (g) $\mathrm{AlMe}_{3}$, toluene.

solvents were purchased from Aldrich Chemical Co. (Milwaukee, WI) and TCI (Tokyo) and used as supplied without further purification. Thin-layer chromatography (TLC) was conducted on precoated silica gel plates (Merck silica gel $60 ; \mathrm{F}_{254},-.25 \mathrm{~mm}$ ) and visualized with either short-wave UV light. Proton nuclear magnetic resonance spectroscopy was performed on a JEOL JNM-LA 300WB spectrometer, and spectra were taken in $\mathrm{CDCl}_{3}$. Unless otherwise noted, chemical shifts are expressed as ppm downfield from tetramethylsilane as the internal standard, and $J$ values are given in Hz. Mass spectroscopy was carried out on VG BIOTECH platform.

Methyl 3-amino-2-(benzyloxycarbonylamino)propanoate (7). To a solution of amino acid $6(7.5 \mathrm{~g}, 31.6 \mathrm{mmol})$ in $\mathrm{MeOH}(200 \mathrm{~mL})$, thionyl chloride $(2.9 \mathrm{~mL}, 41.0 \mathrm{mmol})$ was added dropwise at $0{ }^{\circ} \mathrm{C}$. The reaction mixture was stirred for $2 \mathrm{~h}$ at $0{ }^{\circ} \mathrm{C}$ and for $8 \mathrm{~h}$ at room temperature. After the solvent was removed, the crude residue was treated with diluted aqueous $\mathrm{NaHCO}_{3}$, extracted with EtOAc, washed with water, and dried over anhydrous $\mathrm{Na}_{2} \mathrm{SO}_{4}$. After the solvent was removed, the residue was purified by column chromatography $\left(\mathrm{CHCl}_{3}: \mathrm{MeOH}=10: 1\right)$ to obtain 7 as a colorless solid (6.12 g, 77\%). ${ }^{1} \mathrm{H}$ NMR (300 MHz, $\left.\mathrm{CDCl}_{3}\right) \delta 7.30-$ $7.37(\mathrm{~m}, 5 \mathrm{H}), 5.67(\mathrm{~d}, J=5.4 \mathrm{~Hz}, 1 \mathrm{H}, \mathrm{NH}), 5.12(\mathrm{~s}, 2 \mathrm{H})$, $4.38(\mathrm{~m}, 1 \mathrm{H}, \mathrm{NH}), 3.76(\mathrm{~s}, 3 \mathrm{H}), 3.08(\mathrm{~d}, J=4.9 \mathrm{~Hz}, 2 \mathrm{H}) ; \mathrm{MS}$ (ESI) $m / z 253.5\left([\mathrm{M}+\mathrm{H}]^{+}\right)$.

Methyl 2-(benzyloxycarbonylamino)-3-(2-cyanoethylamino)propanoate (8). To a solution of $7(5.2 \mathrm{~g}, 20.6$ $\mathrm{mmol})$ and triethylamine $(2.9 \mathrm{~mL}, 20.8 \mathrm{mmol})$ in $\mathrm{MeOH}(50$ $\mathrm{mL})$, acrylonitrile $(1.5 \mathrm{~mL}, 22.9 \mathrm{mmol})$ was added for a period of $5 \mathrm{~min}$. The resulting mixture was heated to reflux for $6 \mathrm{~h}$. The solvent was removed under reduced pressure and the residue was purified by column chromatography (hexane:EtOAc $=1: 2)$ to get colorless semisolid $8(5.4 \mathrm{~g}$,
86\%). ${ }^{1} \mathrm{H}$ NMR (300 MHz, $\left.\mathrm{CDCl}_{3}\right) \delta$ 7.28-7.39 (m, 5H), 5.69 (br d, $J=6.9 \mathrm{~Hz}, 1 \mathrm{H}, \mathrm{NH}), 5.12(\mathrm{~s}, 2 \mathrm{H}), 4.46(\mathrm{~m}, 1 \mathrm{H}, \mathrm{NH})$, 3.77 (s, 3H), 3.08 (t, $J=6.3 \mathrm{~Hz}, 2 \mathrm{H}), 2.95(\mathrm{t}, J=6.4 \mathrm{~Hz}, 2 \mathrm{H})$, 2.44 (t, $J=6.9 \mathrm{~Hz}, 2 \mathrm{H})$; MS (ESI) $m / z 306.9\left([\mathrm{M}+\mathrm{H}]^{+}\right)$.

Methyl-(benzyloxycarbonylamino)-3-( $N$-(2-cyanoethyl)3-methoxy-3-oxopropanamido)propanoate (9). $\mathrm{N}$-Methylmorpholine $(3.8 \mathrm{~mL}, 34.7 \mathrm{mmol})$ and methylmalonyl chloride $(2.0 \mathrm{~mL}, 19.0 \mathrm{mmol})$ were added in sequence to the solution of compound 8 (5.3 g, $17.4 \mathrm{mmol})$ in $\mathrm{CH}_{2} \mathrm{Cl}_{2}(100$ $\mathrm{mL})$ at $-15^{\circ} \mathrm{C}$. The resulting mixture was stirred at the same temperature for $2 \mathrm{~h}$ and for $12 \mathrm{~h}$ at room temperature. The crude mixture was extracted with EtOAc, washed with $10 \%$ aq. $\mathrm{KHSO}_{4}$ followed by $10 \%$ aq. $\mathrm{NaHCO}_{3}$. The organic layer was dried over $\mathrm{Na}_{2} \mathrm{SO}_{4}$ and concentrated. The crude residue was purified by flash chromatography (EtOAc) to afford malonamide 9 (4.9 g, 69\%). ${ }^{1} \mathrm{H}$ NMR $(300 \mathrm{MHz}$, $\left.\mathrm{CDCl}_{3}\right) \delta$ 7.31-7.39 (m, 5H), $5.71(\mathrm{~d}, J=4.5 \mathrm{~Hz}, 1 \mathrm{H}, \mathrm{NH})$, $5.11(\mathrm{~s}, 2 \mathrm{H}), 4.53(\mathrm{~m}, 1 \mathrm{H}), 4.55(\mathrm{~s}, 2 \mathrm{H}), 3.81(\mathrm{~s}, 3 \mathrm{H}), 3.73(\mathrm{~s}$, $3 \mathrm{H}), 3.51(\mathrm{t}, J=6.6 \mathrm{~Hz}, 2 \mathrm{H}), 3.43(\mathrm{~d}, J=2.4 \mathrm{~Hz}, 2 \mathrm{H}), 2.66$ (t, $J=6.6 \mathrm{~Hz}, 2 \mathrm{H}$ ); MS (MALDITOF) $\mathrm{m} / \mathrm{z} 405.5\left(\mathrm{M}^{+}\right.$).

Methyl 3-((2-(benzyloxycarbonylamino)-3-methoxy-3oxopropyl)(2-cyanoethyl)amino)-2-diazo-3-oxopropanoate (10). A suspension of malonamide 9 (4.75 g, $11.7 \mathrm{mmol})$, 4acetamidobenzene sulfonyl azide $(2.81 \mathrm{~g}, 11.7 \mathrm{mmol})$ and triethylamine $(1.79 \mathrm{~mL}, 12.8 \mathrm{mmol})$ in dry benzene $(100$ $\mathrm{mL}$ ) was stirred at room temperature for $45 \mathrm{~h}$. The solvent was removed under reduced pressure and the residue was purified by column chromatography (hexane:EtOAc $=1: 2$ ) to obtain diazomalonamide $\mathbf{1 0}$ (3.05 g, 60\%). ${ }^{1} \mathrm{H}$ NMR (300 $\left.\mathrm{MHz}, \mathrm{CDCl}_{3}\right) \delta$ 7.26-7.38 (m, $\left.5 \mathrm{H}\right), 5.71(\mathrm{~d}, J=8.4 \mathrm{~Hz}, 1 \mathrm{H}$, $\mathrm{NH}), 5.10(\mathrm{~s}, 2 \mathrm{H}), 4.63(\mathrm{dd}, \quad J=7.5,15.3 \mathrm{~Hz}, 1 \mathrm{H}), 3.81(\mathrm{~d}$, $J=3.9 \mathrm{~Hz}, 2 \mathrm{H}), 3.80$ (s, $3 \mathrm{H}), 3.79$ (s, $3 \mathrm{H}), 3.56$ (m, $2 \mathrm{H})$, 2.70 (dd, $J=6.9,12.9 \mathrm{~Hz}, 2 \mathrm{H})$, MS (ESI) $m / z 431.4\left(\mathrm{M}^{+}\right)$.

Dimethyl 7-(2-cyanoethyl)-11-(4-methoxyphenyl)-3,8, 
11-trioxo-1-phenyl-2-oxa-4,7,10-triazaundecane-5,9-dicarboxylate (11). A solution of diazomalonamide 10 (2.9 g, $6.7 \mathrm{mmol})$ in toluene $(40 \mathrm{~mL})$ was added the solution of 4methoxybenzamide $(1.01 \mathrm{~g}, 6.7 \mathrm{mmol})$ and rhodium(II)octanoate $(60 \mathrm{mg}, 0.017 \mathrm{mmol})$ in toluene $(40 \mathrm{~mL})$ at $80{ }^{\circ} \mathrm{C}$ for a period of $5 \mathrm{~min}$. After the mixture was heated at the same temperature for $4 \mathrm{~h}$, the solvent was evaporated to dryness and the residue was purified by column chromatography (hexane:EtOAc $=1: 2$ ) to afford $\mathbf{1 1}$ as a diastereomeric mixture (1:1) $(960 \mathrm{mg}, 26 \%) .{ }^{1} \mathrm{H}$ NMR (300 MHz, $\left.\mathrm{CDCl}_{3}\right) \delta 7.81(\mathrm{~d}, J=9.0 \mathrm{~Hz}, 2 \mathrm{H}), 7.78(\mathrm{~d}, J=7.8 \mathrm{~Hz}, 2 \mathrm{H})$, 7.27-7.36 (m, 10H), $6.91(\mathrm{~d}, J=9.0 \mathrm{~Hz}, 2 \mathrm{H}), 6.86(\mathrm{~d}, J=8.1$ $\mathrm{Hz}, 2 \mathrm{H}), 5.29$ (s, 2H), $5.26(\mathrm{~s}, 2 \mathrm{H}), 5.12(\mathrm{~d}, 1 \mathrm{H}), 5.10(\mathrm{~d}$, $1 \mathrm{H}), 4.20(\mathrm{~m}, 1 \mathrm{H}), 4.16(\mathrm{~m}, 1 \mathrm{H}), 3.85(\mathrm{~s}, 3 \mathrm{H}), 3.84(\mathrm{~s}, 3 \mathrm{H})$, $3.83(\mathrm{~s}, 3 \mathrm{H}) 3.80(\mathrm{~s}, 3 \mathrm{H}), 3.68-3.79(\mathrm{~m}, 8 \mathrm{H}), 3.63(\mathrm{~s}, 3 \mathrm{H})$, 3.60 (s, 3H), 2.55 (app t, 2H), 2.59 (app t, 2H); MS (ESI) $\mathrm{m} / \mathrm{z} 555.7\left(\mathrm{M}^{+}\right)$.

Methyl 5-((2-(benzyloxycarbonylamino)-3-methoxy-3oxopropyl)(2-cyanoethyl)amino)-2-(4-methoxyphenyl)oxazole-4-carboxylate (12). To a solution of $11(880 \mathrm{mg}, 1.58$ $\mathrm{mmol})$ in DMF $(3 \mathrm{~mL}), \mathrm{POCl}_{3}(0.14 \mathrm{~mL}, 1.58 \mathrm{mmol})$ was added at room temperature. After the reaction mixture was stirred at $60{ }^{\circ} \mathrm{C}$ for $3 \mathrm{~h}$, the solvent was evaporated. The crude residue was treated with saturated aqueous $\mathrm{NaHCO}_{3}$ solution and it was extracted with EtOAc. The organic layer was dried over anhydrous $\mathrm{Na}_{2} \mathrm{SO}_{4}$ and evaporated. The resulted yellow residue was purified by column chromatography $\left(\mathrm{CHCl}_{3}: \mathrm{MeOH}=10: 1\right)$ to obtain a pale yellow solid 12 (340 mg, 40\%). ${ }^{1} \mathrm{H}$ NMR (300 MHz, $\left.\mathrm{CDCl}_{3}\right) \delta 8.04(\mathrm{~d}, J$ $=9.0 \mathrm{~Hz}, 2 \mathrm{H}), 7.25-7.35(\mathrm{~m}, 5 \mathrm{H}), 6.96(\mathrm{~d}, J=9.0 \mathrm{~Hz}, 2 \mathrm{H})$, $5.64(\mathrm{t}, J=8.7 \mathrm{~Hz}, 1 \mathrm{H}, \mathrm{NH}), 5.12(\mathrm{~s}, 2 \mathrm{H}), 4.59(\mathrm{dd}, J=6.6$, $13.5 \mathrm{~Hz}, 1 \mathrm{H}), 3.88$ (s, 3H), 3.84 (d, $J=7.2 \mathrm{~Hz}, 2 \mathrm{H}), 3.78$ (s, $3 \mathrm{H}), 3.75(\mathrm{~s}, 3 \mathrm{H}), 3.62(\mathrm{t}, J=6.6 \mathrm{~Hz}, 2 \mathrm{H}), 2.65$ (t, $J=6.6$ $\mathrm{Hz}, 2 \mathrm{H}), \mathrm{MS}(\mathrm{ESI}) \mathrm{m} / z$ 537.1 $\left([\mathrm{M}+\mathrm{H}]^{+}\right)$.

Methyl 5-((2-amino-3-methoxy-3-oxopropyl)(2-cyanoethyl)amino)-2-(4-methoxyphenyl)oxazole-4-carboxylate (13). The solution of oxazole $12(270 \mathrm{mg}, 0.50 \mathrm{mmol})$ in $\mathrm{MeOH}(10 \mathrm{~mL})$ was treated with $10 \% \mathrm{Pd}$ on carbon under hydrogen at $1 \mathrm{~atm}$. and stirred at room temperature for $3 \mathrm{~h}$. The reaction mixture was filtered through silica and the filtrate was concentrated. The resulted residue was purified by column chromatography (hexane:EtOAc $=1: 3$ ) to obtain 9 (180 mg, 89\%). ${ }^{1} \mathrm{H}$ NMR (300 MHz, $\left.\mathrm{CDCl}_{3}\right) \delta 7.90$ (d, $J=$ $9.0 \mathrm{~Hz}, 2 \mathrm{H}), 6.93$ (d, $J=9.0 \mathrm{~Hz}, 2 \mathrm{H}), 4.18(\mathrm{~m}, 1 \mathrm{H}), 3.90$ (s, $3 \mathrm{H}), 3.85(\mathrm{~s}, 3 \mathrm{H}), 3.77-3.81(\mathrm{~m}, 4 \mathrm{H}), 3.70(\mathrm{~s}, 3 \mathrm{H}), 2.76(\mathrm{dt}, J$ $=1.5,6.6 \mathrm{~Hz}, 2 \mathrm{H})$; MS (ESI) $m / z 403.4\left([\mathrm{M}+\mathrm{H}]^{+}\right)$.

Methyl 4-(2-cyanoethyl)-2-(4-methoxyphenyl)-8-oxo5,6,7,8-tetrahydro-4H-oxazolo $[5,4-e][1,4]$ diazepine-6-carboxylate (14). To a solution of $13(160 \mathrm{mg}, 0.39 \mathrm{mmol})$ in toluene $(2 \mathrm{~mL}), 2.0 \mathrm{M}$ solution of trimethyl aluminum $(0.19$ $\mathrm{mL}, 0.39 \mathrm{mmol})$ was added at $-10{ }^{\circ} \mathrm{C}$ and the reaction mixture was allowed to stand for $2 \mathrm{~h}$ at room temperature. The solvent was removed under the reduced pressure and the product 14 was separated from the by-products by column chromatography (EtOAc) $(11 \mathrm{mg}, 8 \%) .{ }^{1} \mathrm{H}$ NMR (300 MHz, $\left.\mathrm{CDCl}_{3}\right) \delta 7.85(\mathrm{~d}, J=9.0 \mathrm{~Hz}, 2 \mathrm{H}), 6.96(\mathrm{~d}, J=8.4 \mathrm{~Hz}, 2 \mathrm{H})$, $3.91(\mathrm{t}, J=3.9 \mathrm{~Hz}, 1 \mathrm{H}), 3.87$ (s, 3H), $3.83(\mathrm{~s}, 3 \mathrm{H}), 3.69$ (d, $J$ $=4.2 \mathrm{~Hz}, 2 \mathrm{H}), 3.57(\mathrm{t}, J=5.7 \mathrm{~Hz}, 2 \mathrm{H}), 2.63(\mathrm{t}, J=6.0 \mathrm{~Hz}$, 2H); MS (ESI) $m / z 371.1\left([\mathrm{M}+\mathrm{H}]^{+}\right)$.

Acknowledgments. This study was supported by the grant of the Korea Healthcare technology R\&D Project, Ministry for Health and Welfare, Republic of Korea (A090352) and the National Research Foundation of Korea (NRF) grant funded by the Korea government (MEST) (No.20100017290).

\section{References}

1. Sternbach, L. H. J. Med. Chem. 1979, 22, 1.

2. Bock, M. G.; Dipardo, R. M.; Evans, B. E.; Rittle, K. E.; Whitter, W. L.; Veber, D. F.; Anderson, P. S.; Freidinger, R. M. J. Med. Chem. 1989, 32, 13.

3. Romer, D.; Buscher, H. H.; Hill, R. C.; Maurer, R.; Petcher, T. J.; Zeugner, H.; Benson, W.; Finnner, E.; Milkowski, W.; Thies, P. W. Nature 1982, 298, 759.

4. Kornecki, E.; Ehrlich, Y. H.; Lenox, R. H. Science 1984, 226, 1454.

5. Hsu, M. C.; Schutt, A. D.; Hooly, M.; Slice, L. W.; Sherman, M. I.; Richman, D. D.; Potash, M. J.; Volsky, D. J. Science 1991, 254, 1799.

6. Pauwels, R.; Andries, K.; Desmyter, J.; Schols, D.; Kukla, M. J.; Breslin, H. J.; Raeymaeckers, A.; Van Gelder, J.; Woestenborghs, R.; Heykants, J.; Schellekens, K.; Janssen, M. A. C.; Clercq, E. D.; Janssen, P. A. J. Nature 1990, 343, 470.

7. James, G. L.; Goldstein, J. L.; Brown, M. S.; Rawson, T. E.; Somers, T. C.; McDowell, R. S.; Crowley, C. W.; Lucas, B. K.; Levinson, A. D.; Marsters, J. C. Science 1993, 260, 1937.

8. Gregson, S. J.; Howard, P. W.; Corcoran, K. E.; Barcella, S.; Yasin, M. M.; Hurst, A. A.; Jenkins, T. C.; Kelland, L. R.; Thurston, D. E. Bioorg. Med. Chem. Lett. 2000, 10, 1845.

9. Gregson, S. J.; Howard, P. W.; Corcoran, K. E.; Jenkins, T. C.; Kelland, L. R.; Thurston, D. E. Bioorg. Med. Chem. Lett. 2001, $11,2859$.

10. Kornecki, E.; Ehrlich, Y. H.; Lenox, R. H. Science 1984, 226, 1454.

11. Lisowski, V.; Fabis, F.; Pierre, A.; Caignard, D. H.; Renard, P.; Rault, S. J. Enzym. Inhib. Med. Chem. 2002, 17, 403.

12. Thurston, D. E.; Bose, D. S.; Howard, P. W.; Jenkins, T. C.; Leoni, A.; Baraldi, P. G.; Guiotto, A.; Cacciari, B.; Kelland, L. R.; Foloppe, et. J. Med. Chem. 1999, 42, 1951.

13. Fegeler, J. J.; Gardenhire, E. M.; Helsley, G. C. US 4897392 , 1990; Chem. Abstr. 113, 40741.

14. Fiakpvi, C. Y.; Phillips, O. A.; Murthy, K. S. K.; Knavs, E. E. Drug Des. Discovery 1993, 45.

15. PCT Int. Appl., 2007073296, 2007.

16. Harrison, R. G.; Jolley, M. R. J.; Saunders, J. C. Tetrahedron Lett. 1976, 17, 293

17. Mark, J. T.; Harry, A.; Beining, C. J. Org. Chem. 2009, 74, 3856.

18. Kislyi, V. P.; Danilova, E. B.; Semenov, V. V.; Yakovenko, A. A.; Dolgushin, F. M. Russ. Chem. Bull., Int. Ed. 2006, 55, 1840.

19. Bristol-Myers Squibb Company, Patent: EP372582 A3, 1991.

20. Ziegler, K.; Schneider, K.; Schneider, J. Liebigs Ann. Chem. 1959, $623,9$.

21. Compound 18: ${ }^{1} \mathrm{H} \mathrm{NMR}\left(400 \mathrm{MHz}, \mathrm{CDCl}_{3}\right) \delta 8.26(\mathrm{~d}, J=9.2 \mathrm{~Hz}$, $2 \mathrm{H}), 7.50(\mathrm{~m}, 3 \mathrm{H}), 4.89$ (br s, $1 \mathrm{H}), 3.32$ (t, $J=9.2 \mathrm{~Hz}, 2 \mathrm{H}), 3.12(\mathrm{~s}$, $3 \mathrm{H}), 2.81(\mathrm{t}, J=10.8 \mathrm{~Hz}, 2 \mathrm{H})$; MS (ESI) $m / z 262.2\left([\mathrm{M}+\mathrm{H}]^{+}\right)$. 